\title{
Integrated Approach for the Management of Colletotrichum lindemuthianum (L.) Savi Causing Anthracnose of Cowpea
}

\author{
Shameem Ahmad*, Prashant Mishra, Sandeep Kumar and Mod. Ali \\ Department of Plant Pathology, SVPUA\&T, Meerut- 250110, UP, India \\ *Corresponding author
}

\section{A B S T R A C T}

Keywords

Soil borne, Bioagents, Botanicals, Disease intensity and Incidence

Article Info

Accepted: 06 May 2018 Available Online:

10 June 2018
Cowpea [Vigna sinensis (L.) Savi] is an ancient legume crops and major source of protein. The cowpea is affected by various fungal diseases. Among those Colletotrichum lindemuthianum is a seed and soil borne fungus causing the anthracnose disease in Cowpea. Most of the promising cowpea cultivars are under a great threat for profitable cultivation due to the attack of Fungi, bacteria, virus and nematodes. The major losses of cowpea are covered by fungi, in which anthracnose caused by Colletotrichum lindemuthianum is more important. A various bio-agents, botanicals and fungicide were applied for integrated management of pathogen. The minimum disease intensity $(13.63 \%)$ and disease incidence $(16.67 \%)$ was recorded in treatments T9 (Carbendazim12\%+ mancozeb 63\%) SAAF @ $0.2 \%$ followed by $(14.61 \%$ and $23.33 \%)$ in treatment T4 (Copper oxy chloride @ 0.2\%) and seed treatments with Ajwain seed extract + spray of Ajwain seed extract was found effective in reducing disease incidence (42.97\%) and increase in grain yield (54.86). Application of Trichoderma as seed treatment + foliar spray were also effective in reduce disease incidence $(39.00 \%)$ and increase grain yield $(50.00 \%)$.

\section{Introduction}

Most of the pulses still await significant breakthrough in terms of production and productivity. The total pulse production in the country is almost static although substantial productivity improvement in most of the pulse crop has been made. The static pulse production is mainly due to poor adoption of improved varieties, production technologies and disease management practices by farmers. Cowpea is mainly grown in India. It is used for dal, vegetable and fodder. The total world average under pulses, as recorded during
2013-14, is about 807.54 lakh ha area, production at 730.07 lakh tonnes and productivity $904 \mathrm{~kg} / \mathrm{ha}$ in particular cowpea total world area. In northern India it is grown in Uttar Pradesh, Punjab, Delhi and Haryana. All India area, production and average yield of cowpea is 3569 hectare, 2993 tonnes and 607 $\mathrm{kg} /$ hectare respectively (Source: IIPR, 2013 2014). However promising cowpea cultivars are under a great threat for profitable cultivation due to the attack of biotic factors viz., Fungi, bacteria, virus, nematode and abiotic factors like nutritional deficiency toxicity water stress, temperature etc. Most of 
the popular disease found in cowpea crop Anthracnose (C. lindemuthianum). Anthracnose characterized by sunken, black lesion is one of the major fungal diseases of cowpea which constrain its economic production (Enyiukwu and Awurum, 2013b). In affected cowpea plant, up to 50 per cent yield reduction occurs. Its causal agent has been a subject of much scientific debate. It has been variously advanced and reported as a form of Colletotrichum lindemuthianum (Masangwa et al., 2013). The management of the disease can be done through cultural practice, chemical, biological practice and use of resistant variety. But there is no doubt that application of chemicals practice for management of anthracnose is the most effective and widely recommended method of disease management.

\section{Materials and Methods}

Field experiments were conducted during crop season of the year 2016-2017 at students' instructional farm, Sardar Vallabhbhai Patel University of Agriculture and Technology, Meerut.

The efficacy of fungicides, botanicals and bioagents by seed treatment and foliar spray and alone against the pathogen were tested in field during 2016-017. The seed variety Triveni was sown in plots size $3 \times 2 \mathrm{~m}\left(6 \mathrm{~m}^{2}\right)$ size and the experiments were laid down in Randomized Block Design (RBD) with three replication. The soil of experimental plot was sandy loam in nature, well drained with low $\mathrm{C}$ : $\mathrm{N}$ ratio. One treatment served as control which was without any treatment $15 \mathrm{~g}$ seed were sown at $35 \times 25 \mathrm{~cm}$ spacing in each plots. For soil application of the bio-agent and Trichoderma powder was thoroughly mixed with FYM separately, one week before application and was mixed in the soil before sowing. The first spray of fungicides, botanicals and bio-agent was given just after the appearance of the disease and subsequent two spraying were given at an interval of 10 days. Standard agronomical practices were followed as per recommendations. All the inputs (treatments) are shown in Table 1 and observation on disease intensity and Table 2 disease incidence were recorded after 10 days of last spraying. Yield data were also recorded separately for each plot after harvesting the crop and calculated on per ha basis.

\section{Progression of disease}

\section{Disease intensity on leaves \%}

Observations on anthracnose intensity were recorded on selected cowpea plants, applying standard 0-9 grade disease rating scale (Mayee and Datar, 1986) as given below:

\section{Standard disease rating (0-9 grade) scale}

\section{Rating scale - Description}

$0=$ No symptoms on the leaf.

$1=$ Small, irregular brown spots covering 1 per cent or less of the leaf area.

$3=$ Small, irregular, brown spots with concentric rings covering 1-10 per cent of the leaf area.

5 = Lesions enlarging, irregular, brown with concentric rings covering 11-25 per cent of the leaf area.

7 = Lesions coalescing to form irregular brown patches with concentric rings. Covering 26-50 per cent of the leaf area. Lesions also on stem and petioles.

$9=$ Lesions coalescing to form irregular, dark brown patches with concentric rings covering 51 per cent or more of the leaf area. Lesions on stem and petioles. 
Based on numerical ratings or scale observed per cent disease intensity was worked out applying the formula given by Mc Kinney (1923).

Summation of numerical rating Percent Intensity Disease $=$-------------- $\times 100$ Number of leaves/plant observed $X$ Maximum rating

\section{Disease incidence}

Ten plants from each plot were selected and tagged. Observations were recorded after disease appearance on cow pea plant and calculated disease incidence applying the formula.

Disease incidence $=\frac{\text { Number of infected plant }}{\text { Total no. of plant }}$

\section{Test weight}

Seed weight refers the weight of 1,000 seeds according to ISTA.

Weigh 100 seeds for 8 replicates, separately

Calculate the average weight of 100 seeds, and multiply by 10

1000 seeds weight $=100$ seeds weight $\times 10$

\section{Results and Discussion}

The experiments were revealed that out of 10 treatments using fungicides, bio-agent and botanicals formulations was conducted during 2016-17. In the field experiments have been considered as a novel approach for managing plant diseases, as it requires low amount of chemicals, reduces the cost of control as well as pollution hazards. Integration of chemical and non-chemical method involving fungicide, botanical and bio-agent was carried out under field conditions for the management of anthracnose of cowpea reduced the disease intensity of anthracnose under field condition. The treatment, Carbendazim 12\% + Mancozeb $63 \%$ (SAAF) @ $0.2 \%$ most effective in reducing the disease intensity $(13.63 \%)$ and followed by the Copper oxy chloride @ 0.2\% spray (14.61\%), Tebuconazole @ 0.05\% spray $(15.05 \%)$.

The other treatments found effective were the botanical -Ajwain seed extract ST+ Ajwain seed extract FS (17.14\%). Bio-agent was reduction disease intensity Trichoderma ST + Trichoderma FS (17.26\%), Captan seed treatments@0.5\% + Eucalyptus FS (18.05\%), Trichoderma ST @ 5.0\% + Mancozeb FS at reduces $(23.28 \%)$. The maximum disease intensity was found in Ajwain seed extract @ $5.0 \%$ + Chlorothalonil FS at (29.33\%) as compare to control $39.62 \%$ after spray respectively. Several workers were reported of fungicide to control anthracnose disease and increase the yields earlier by (Kumar and Mukhopadhyay, 1990; Bharadwaj and Thakur, 1991; Mittal, 2001; Gawande et al., 2009 and Singh, 2010).

Efficacy of botanicals and bio-agents Trichoderma against Colletotrichum species reported earlier by several workers (Chandrasekaran et al., 2000; Gupta et al., 2005; Santra et al., 2008; and Gawande et al., 2009). The botanicals and bio-agents found effective against $C$. lindemuthianum in present studies were also reported effective against Colletotrichum species earlier by several workers (Chandrasekharan et al., 2000; and Kaur et al., 2006).

\section{Effect of different treatments on disease incidence}

In the field experiments the result in close agreement with the observation recorded during 2016-17. 
Table.1 Effect of fungicides, botanicals and bio-agents sprayings on anthracnose Percent Disease Intensity (PDI) in cowpea

\begin{tabular}{|l|l|l|l|l|l|}
\hline $\begin{array}{l}\text { S. } \\
\text { No. }\end{array}$ & Treatments & Concentration & $\begin{array}{l}\text { PDI Before } \\
\text { I Spray }\end{array}$ & $\begin{array}{l}\text { After I } \\
\text { Spray }\end{array}$ & $\begin{array}{l}\text { After II } \\
\text { Spray }\end{array}$ \\
\hline 1. & Trichoderma ST + Mancozeb FS & $2.0 \%$ & 26.48 & 24.48 & 23.28 \\
\hline 2. & Captan ST+ Eucalyptus FS & $0.5 \%$ & 23.00 & 19.14 & 18.05 \\
\hline 3. & $\begin{array}{l}\text { Ajwain extract ST+ Chlorothalonil } \\
\text { FS }\end{array}$ & $5.0 \%$ & 30.98 & 30.50 & 29.33 \\
\hline 4. & Copper oxy chloride FS & $0.2 \%$ & 18.00 & 15.65 & 14.61 \\
\hline 5. & Hexaconazole spray & $0.05 \%$ & 20.05 & 16.43 & 15.43 \\
\hline 6 & Trichoderma ST + FS & $2.0 \& 5.0 \%$ & 22.26 & 19.26 & 17.26 \\
\hline 7 & Ajwain seed extract ST + FS & $5.0 \& 5 \%$ & 20.43 & 17.92 & 17.14 \\
\hline 8 & Tebuconazole FS & $0.05 \%$ & 19.61 & 15.95 & 15.05 \\
\hline 9 & $\begin{array}{l}\text { Carbendazim } \text { 12\% } \\
\text { Mancozeb 63\% (SAAF) }\end{array}$ & $0.2 \%$ & 17.05 & 15.00 & 13.63 \\
\hline $\mathbf{1 0}$ & $\begin{array}{l}\text { Control } \\
\text { C.D. at 5\% }\end{array}$ & & 30.83 & 34.21 & 39.62 \\
\hline SE(m) & & $\mathbf{2 . 2 8}$ & $\mathbf{2 . 5 8}$ & $\mathbf{2 . 3 8}$ \\
\hline
\end{tabular}

Mean of three replications: ST- seed treatments, FS- foliar spray

Table.2 Integrated disease management against anthracnose of cowpea caused by Colletotrichum lindemuthianum

\begin{tabular}{|c|c|c|c|c|c|c|}
\hline $\begin{array}{l}\text { S. } \\
\text { No. }\end{array}$ & Treatments & $\begin{array}{l}\text { AV. Disease } \\
\text { Incidence } \\
(\%)\end{array}$ & $\begin{array}{l}\text { Reduction in } \\
\text { disease } \\
\text { Incidence }(\%)\end{array}$ & $\begin{array}{l}1000 \\
\text { grain } \\
\text { weight }\end{array}$ & $\begin{array}{l}\text { Yield } \\
\text { (q/ha.) }\end{array}$ & $\begin{array}{l}\text { Increase } \\
\text { in grain } \\
\text { yield }(\%)\end{array}$ \\
\hline 1. & $\begin{array}{lr}\text { Trichoderma } & \mathrm{ST}+ \\
\text { Mancozeb FS } & \end{array}$ & 36.66 & 35.29 & 135.0 & 9.72 & 35.00 \\
\hline 2. & $\begin{array}{l}\text { Captan ST + } \\
\text { Eucalyptus FS }\end{array}$ & 35.33 & 37.66 & 140.23 & 10.08 & 40.00 \\
\hline 3. & $\begin{array}{l}\text { Ajwain seed extract+ } \\
\text { Chlorothalonil FS }\end{array}$ & 37.00 & 34.69 & 134.93 & 9.72 & 34.86 \\
\hline 4. & Copper oxycholoride & 23.33 & 58.82 & 169.23 & 12.18 & 69.16 \\
\hline 5. & Hexaconazole & 30.00 & 47.05 & 160.00 & 11.52 & 60.00 \\
\hline 6. & Trichoderma ST + FS & 34.56 & 39.00 & 150.00 & 10.80 & 50.00 \\
\hline 7. & $\begin{array}{l}\text { Ajwain seed extract }+ \\
\text { Ajwain FS }\end{array}$ & 32.31 & 42.97 & 150.54 & 11.15 & 54.86 \\
\hline 8. & Tebuconazole FS & 29.95 & 47.14 & 165.00 & 11.88 & 65.00 \\
\hline 9. & $\begin{array}{l}\text { Carbendazim + } \\
\text { Mancozeb (SAAF) }\end{array}$ & 16.67 & 70.57 & 174.00 & 12.52 & 73.88 \\
\hline \multirow[t]{3}{*}{10.} & Control & 56.66 & 0 & 100.00 & 7.200 & 0 \\
\hline & CD. 5\% & 2.92 & & 4.06 & 1.421 & \\
\hline & SE(m) & 0.97 & & 1.35 & 0.47 & \\
\hline
\end{tabular}


On the incidence of Colletotrichum lindemuthianum on cowpea plant showed mean disease incidence presented in Table 2 indicate that foliar spray with Carbendazim + Mancozeb (SAAF) @ 0.2\% concentration and significantly reduced the disease incidence and increased the grain yield $(70.57 \%$ and yield $12.52 \mathrm{q} / \mathrm{ha}$ ) followed by Copper oxy chloride resulted in the reduction in disease incidence up to $(58.82 \%$ and yield 12.18q/ha.), Tebuconazole (47.14\% and yield 11.88q/ha.) Ajwain seed extract ST + Ajwain seed extract FS (42.97\% and yield $11.15 \mathrm{q} / \mathrm{ha})$, Trichoderma ST + Trichoderma FS (39.00\% and yield 10.80 q/ha.), Captan ST+ Eucalyptus FS (37.66\%, and yield 10.08q/ha.) Minimum reduction disease incidence was found in Trichoderma ST+ Mancozeb FS and Ajwain seed extract ST+ Chlorothalonil FS (35.29\% and 34.69\%) also which gave minimum increase in yield $(9.72 \mathrm{q} / \mathrm{ha}$ and 9.71q/ha) as compare to control. The incidence of $C$. truncatumon soyabean plant in advance varietal trial I and II showed mean incidence of $50 \%$ and $34 \%$ respectively (Anon. 1989). Laxman (2006) reported $18.20 \%$ to $86.57 \%$ incidence of the green gram anthracnose.

\section{References}

Bharadwaj, C. L. and Thakur, D. R., (1991). Efficacy and economics of fungicide spray schedules for control of leaf spots and pod blights in urdbean, Indian Phytopathology 44 (4): pp 470-475.

Chandrasekaran, A., Narasimhan, V. and Rajappan, K. (2000). Integrated management of anthracnose and pod blight of soybean, Ann. Pl. Prot. Sci. 8: 163-165.

Enyiukwu, D.N. and Awurum, A.N. (2013b). Fungi toxic effects of Carica papaya and Piper guineense extracts against Colletotrichum destructivum in the glasshouse ContinentalJ. Agric. Sci., 7(1): 23-28.

Gawande, D. B., Suryawanshi, A. P., Pawar, A. K., Apet, K. T. and Devgire, S. S. (2009). Field evaluation of fungicides, botanicals and bioagents against anthracnose of soybean. Agric. Sci. Digest. 29 (3): 174-177.

Gupta, S., Kalha, C. S., Vaid, A. and Rizvi, S. E. H. (2005). Integrated management of anthracnose of French bean caused by C. lindemuthianum. J. Mycol. Pl. Pathol. 35 (3): 432-436.

IIPR (2011).Vision 2030 Document. Indian Institute of Pulses Research (IIPR), ICAR, Kanpur, India.

Jukanti A. K, Gaur P. M, Gowda C. L. L. and Chibbar R. N. (2012). Nutritional quality and health benefits of chickpea (Cicer arietinum L.): a review British Journal of Nutrition, 108, S11-S26.

Kaur, M., Sharma, O. P. and Sharma, P. N. (2006).In -vitro effect of Trichoderma species on $C$. capsici causing fruit rot of chilli. Indian Phytopath. 59(2): 243245.

Kinney M.C. (1923). A new system of grading plant disease J. Agric. Res. 26:195-218.

Kumar, R. and Mukhopadhyay, A. N. (1990).Chemical control of anthracnose of Urdbean in field condition Indian Phytopath.43: 102-105.

Laxman, R, (2006). Studies on leaf spot of greengram caused by Colletotrichum truncatum (Schw.) Andrus and Moore. M. Sc. (Agri.) Thesis, Univ. Agric. Sci., Dharwad, Karnataka, India.

Masangwa, J.I.G., Aveling, T.A.S. and Kritziger, Q. (2013).Screening of plant extracts for antifungal activities against Colletotrichum species of common bean (Phaseolus vulgaris) and cowpea (Vigna unguiculata L.) J. Agric Sci., 151 (4): 482-491 
Mayee, C.D. and Datar, V.V. (1986). Santra, S., Chatterjee, N. C. and Dutta, S. Phytopathometry Tech. Bull-1 marathwada Agric. Univ., Parbhani. pp. 66.

Mittal, R. K. (2001). Yield losses by Frog-eye leaf spot and anthracnose disease in soybean under different sowing dates in the hills Indian Phytopath. 54(1): 32-34. (2008). Integrated approach to control anthracnose (Colletotrichum gloeosporiodes) disease of Saracaasoca. J. Mycol. Pl. Pathol. 38 (3): pp-639-642 Singh, A. K. (2010). Integrated management of Cereospora leaf spot of urdbean (Vigna mungo). J. Mycol. Pl. Pathol. 40 (4): 595.

\section{How to cite this article:}

Shameem Ahmad, Prashant Mishra, Sandeep Kumar and Mod. Ali. 2018. Integrated Approach for the Management of Colletotrichum lindemuthianum (L.) Savi Causing Anthracnose of Cowpea. Int.J.Curr.Microbiol.App.Sci. 7(06): 1113-1118.

doi: https://doi.org/10.20546/ijcmas.2018.706.132 